\title{
Life Cycle Assessment and Life Cycle Cost Analysis of Magnesia Spinel Brick Production
}

\author{
Aysun Özkan ${ }^{1, *}$, Zerrin Günkaya ${ }^{1}$, Gülden Tok ${ }^{1,2}$, Levent Karacasulu ${ }^{1,3}$, Melike Metesoy ${ }^{4}$, \\ Müfide Banar ${ }^{1}$ and Alpagut Kara ${ }^{2,3}$ \\ 1 Department of Environmental Engineering, Faculty of Engineering, Anadolu University, \\ Eskişehir 26555, Turkey; zcokaygil@anadolu.edu.tr (Z.G.); gyet@anadolu.edu.tr (G.T.); \\ lkaracasulu@anadolu.edu.tr (L.K.); mbanar@anadolu.edu.tr (M.B.) \\ 2 Ceramic Research Center Inc., Eskişehir 26555, Turkey; akara@anadolu.edu.tr \\ 3 Department of Materials Science and Engineering, Faculty of Engineering, Anadolu University, \\ Eskişehir 26555, Turkey \\ 4 Sörmaş Sögüut Refractory Materials Inc., Bilecik 11660, Turkey; melike.metesoy@sormas.com.tr \\ * Correspondence: aysunozkan@anadolu.edu.tr; Tel.: +90-222-321-3550 (ext. 6400) \\ Academic Editor: P.V. Kandachar \\ Received: 13 April 2016; Accepted: 5 July 2016; Published: 20 July 2016
}

\begin{abstract}
Sustainable use of natural resources in the production of construction materials has become a necessity both in Europe and Turkey. Construction products in Europe should have European Conformity (CE) and Environmental Product Declaration (EPD), an independently verified and registered document in line with the European standard EN 15804. An EPD certificate can be created by performing a Life Cycle Assessment (LCA) study. In this particular work, an LCA study was carried out for a refractory brick production for environmental assessment. In addition to the LCA, the Life Cycle Cost (LCC) analysis was also applied for economic assessment. Firstly, a cradle-to-gate LCA was performed for one ton of magnesia spinel refractory brick. The CML IA method included in the licensed SimaPro 8.0.1 software was chosen to calculate impact categories (namely, abiotic depletion, global warming potential, acidification potential, eutrophication potential, human toxicity, ecotoxicity, ozone depletion potential, and photochemical oxidation potential). The LCC analysis was performed by developing a cost model for internal and external cost categories within the software. The results were supported by a sensitivity analysis. According to the results, the production of raw materials and the firing process in the magnesia spinel brick production were found to have several negative effects on the environment and were costly.
\end{abstract}

Keywords: CML method; firing process; global warming potential; Life Cycle Assessment (LCA); Life Cycle Cost (LCC); magnesia spinel brick; refractory production

\section{Introduction}

Refractories are indispensable in almost all ferrous and non-ferrous industries where high temperature furnace or kilns are being used. More than half of refractory products are preferred in the steel industry, followed by the cement and lime and ferrous and non-ferrous industries. The others are employed in the ceramic and glass industry, incineration, the chemical industry, and many more. Magnesia spinel bricks are generally used in the cement and steel industries. Worldwide, 8 million tons of refractories are produced on a yearly basis. Consequently, sustainable production of these products has become very important.

Various methods are employed by the refractory industry in the manufacture of bricks. The simplest procedure is to saw shapes from natural or artificially produced raw materials. Highly refractory materials are nowadays manufactured increasingly by fine crushing and wet mixing 
and afterwards the refractory materials are formed by means of extrusion, slip casting, or pressing (hydraulic or isostatic). The production process includes the stages of raw materials storage, raw materials preparation, shaping, drying, firing, and subsequent treatment. Refractory products are fired at temperatures between 1250 and $1850{ }^{\circ} \mathrm{C}$. Magnesia spinel bricks are fired at $1760-1850{ }^{\circ} \mathrm{C}$ in tunnel kilns and the minimum specific energy requirement for $1 \mathrm{~kg}$ magnesite brick is $6000-9700 \mathrm{~kJ} / \mathrm{kg}$ [1]. In addition to various gaseous emissions, emissions to water and soil result from refractory plants depending on the types of raw materials, fuels, and production processes, especially from drying and firing processes. Several studies have already been conducted on the recycling of refractory materials. Recycling of MgO refractories from electric arc furnaces was studied by Lule-Gonzalez et al. (2005), the recovery and recycling of scrap refractories was studied by Valoref (1998), and the steel industry and the recycling of refractories were investigated by Nakamura et al. (1999) [2-4].

Refractory production is covered by the Turkish Regulation on Monitoring of Greenhouse Gas (GHG), in force since 2014 [5]. In accordance with the regulation, refractory production facilities should monitor the GHG emissions arising from plants and form a GHG monitoring plan. On the other hand, sustainable use of natural resources in the production of construction materials has become a necessity in Europe and also in Turkey to comply with the requirements of the European market. The European Construction Products Directive (89/106/EEC) [6], which was adopted in 1989, includes building materials such as bricks, sanitaryware, wall, floor and porcelain tiles, technical ceramics, and refractory materials. As for the other construction materials, refractories used in Europe should have European Conformity (CE) and Environmental Product Declaration (EPD) certificates, as per the related Directive. EPD is a certificate that provides relevant, verified, quantitative, and comparable information about the environmental impact of materials. An EPD certificate can be granted by performing a Life Cycle Assessment (LCA) study, which is a technique to evaluate all environmental impacts associated with all the stages of an action or a product's life.

LCA is a methodology for evaluating the environmental loads of processes and products during their whole life cycle. The assessment includes the entire life cycle of a product, process, or system, encompassing the extraction and processing of raw materials; manufacturing, transportation, and distribution; use, reuse, maintenance, recycling, and final disposal. LCA has become a widely used methodology because of its integrated way of treating the framework, impact assessment, and data quality [7].

Construction materials have become a hot topic in LCA research in recent decades. Glass, aluminum alloy, stone, and ceramic materials have been analyzed as typical construction materials by using the LCA [8-11] and Life Cycle Energy Analysis (LCEA) methods [12]. Besides, some LCA studies have been conducted for a number of ceramic products [13-19] and they have all reported the high energy consumption in the ceramic manufacturing stage (production process), especially during firing. Additionally, LCA has also been widely applied to assess the environmental impacts of the cement production process [20-26]. LCA and LCC methods are the most important tools approaching from the raw material of a product until the end use for all phases [27]. The LCC method used in this study is the economic equivalent of the LCA method. IEC 60300-3-3 Life Cycle Cost Implementation Guide has emerged as a standard of all applications with the general introduction of the LCC concept. According to the IEC 60300-3-3 standard, LCC analysis consists of four stages: research and development costs, construction costs, production costs, and disposal costs [28-30]. A systematic model for building construction material has been developed to optimize carbon dioxide emissions and environmental costs by addressing fossil fuels, electricity, and water consumption in the construction sector by Chou and Yeh (2015) [31]. Abdul-Wahab et al. (2015) have developed a new model for cost reduction efforts as well as reduction of the environmental impact of cement production [32].

However, there is a dearth of literature on LCA and LCC studies of refractory brick production. In this context, the aim of this study is make an environmental and economic assessment of refractory brick production processes by using these methods. For this aim, licensed SimaPro 8.0.1 software 
(Amersfoort, The Netherlands) was used to calculate different environmental impact categories. In addition, the internal and external costs of the magnesia spinel brick were obtained by LCC method. Finally, a sensitivity analysis was performed with 'what-if' scenarios to determine the changes on the LCA results.

\section{Materials and Methods}

\subsection{Life Cycle Assessment}

The LCA technique used in this study is based on the ISO 14040 and ISO 14044 guidelines and requirements, consisting of four steps; goal and scope definition, inventory analysis, impact assessment, and interpretation [33-36]. Data regarding the production process were obtained from the refractory plant, the relevant literature [37], and also from the software database. CML (Center of Environmental Science of Leiden University) IA method included in licensed SimaPro 8.0.1 software was used for the assessment from the perspectives of impact categories. The impact assessment method implemented as CML-IA methodology is defined for the midpoint approach [38]. LCC analysis was carried out to develop a new economic method for internal cost (i.e., energy, materials, and transport) and external cost (i.e., environmental) categories by using licensed SimaPro 8.0.1 software [39].

\subsubsection{Goal and Scope Definition}

The main goal of this study is to identify key issues associated with the life cycle of a magnesia spinel refractory brick. One ton of magnesia spinel refractory brick was chosen as the functional unit. The characteristics of magnesia spinel brick are summarized in Table 1. A cradle-to-gate LCA was performed and system boundaries are given in Figure 1. Infrastructure was excluded from the system boundary. Solid waste from production below $2.5 \%$ was neglected.

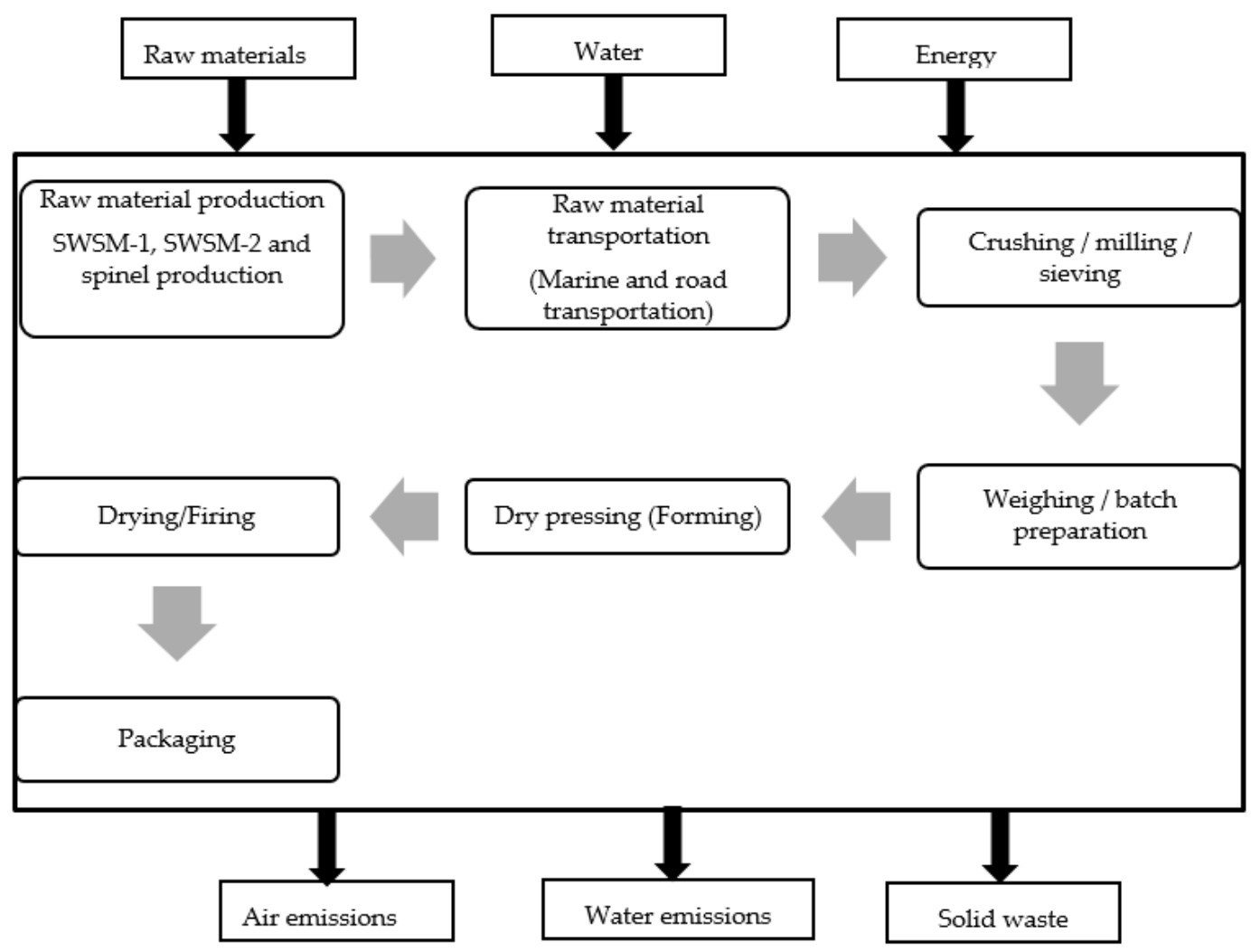

Figure 1. System boundaries (SWSM: seawater sintered spinel). 
Table 1. Characteristics of the magnesia spinel refractory brick.

\begin{tabular}{cc}
\hline Control Properties & Values \\
\hline Bulk density $\left(\mathrm{g} / \mathrm{cm}^{3}\right)$ & 2.95 \\
Apparent porosity $(\%)$ & 16 \\
Cold crushing strength $\left(\mathrm{N} / \mathrm{mm}^{2}\right)$ & 75 \\
\hline Chemical analysis $(\mathrm{wt} \%)$ & \\
\hline $\mathrm{MgO}$ & 89.0 \\
$\mathrm{Al}_{2} \mathrm{O}_{3}$ & 9.0 \\
$\mathrm{SiO}_{2}$ & 0.3 \\
$\mathrm{CaO}$ & 0.8 \\
$\mathrm{Fe}_{2} \mathrm{O}_{3}$ & 0.5 \\
\hline Design properties & \\
\hline Refractoriness under load, ${ }^{\circ} \mathrm{C}$ & $>1750$ \\
Thermal expansion $\left(1000{ }^{\circ} \mathrm{C}, \%\right)$ & 1.5 \\
\hline
\end{tabular}

\subsubsection{Life Cycle Inventory Analysis}

Environmental impacts of one ton refractory brick are determined by data groups of stages of raw material production, energy consumption, atmospheric emissions, and waste generation. The data were taken from the brick production plant in Turkey, on-site measurements, and EcoInvent (v.3), included in SimaPro 8.0.1.

Raw Material Production

The raw material used for the production of refractory bricks was seawater-sintered magnesia (SWSM) $(85 \%)$ and sintered spinel (15\%). Half of the seawater-sintered magnesia used in refractory brick was provided from Mexico (SWSM-1); the other half is obtained from Netherlands (SWSM-2). The sintered spinel was provided from China. The raw materials were transported to the refractory brick plant by marine and road transportation.

In the SWSM process, magnesium hydroxide $\left(\mathrm{Mg}(\mathrm{OH})_{2}\right)$ is precipitated from magnesium chloride $\left(\mathrm{MgCl}_{2}\right)$ and dolomitic lime (including $\mathrm{CaO}$ and $\mathrm{MgO}$ ). The precipitated $\mathrm{Mg}(\mathrm{OH})_{2}$ is thickened, washed, and dewatered using rotary vacuum filters. Then, a $\mathrm{Mg}(\mathrm{OH})_{2}$ filter cake is calcined in multiple-hearth furnaces at about $1000^{\circ} \mathrm{C}$ to create caustic magnesia, a fine magnesium oxide powder. After calcination, the caustic magnesium oxide $(\mathrm{MgO})$ is compacted into briquettes and densified by sintering in vertical shaft kilns at temperatures of over $1900^{\circ} \mathrm{C}$. Life cycle inventory data for one ton of SWSM (MgO) obtained from related plants and literature [37] are shown in Table 2.

Table 2. Life cycle inventory data of SWSM.

\begin{tabular}{cccccc}
\hline Natural Resources & Unit & Amount & Emissions & Unit & Amount \\
\hline $\mathrm{MgCl}_{2}$ & $\mathrm{~kg}$ & 1200 & $\mathrm{SO}_{2}$ & $\mathrm{~kg}$ & $7-0.6$ \\
Water & $\mathrm{m}^{3}$ & 20 & $\mathrm{CO}_{2}$ & $\mathrm{~kg}$ & 570 \\
Materials and energy & & & $\mathrm{NO}_{\mathrm{x}}$ & $\mathrm{kg}$ & $2.32-3.25$ \\
Natural gas & $\mathrm{GJ}$ & 11.04 & $\mathrm{CO}$ & $\mathrm{kg}$ & $3.35-9$ \\
$\mathrm{MgO}$ & $\mathrm{kg}$ & 502 & Particulate matter & $\mathrm{kg}$ & $1.32-0.3$ \\
$\mathrm{CaO}$ & $\mathrm{kg}$ & 698 & $\mathrm{~B}$ & $\mathrm{~g}$ & 50 \\
Electricity & $\mathrm{kWh}$ & 72.22 & $\mathrm{Cr}$ & $\mathrm{g}$ & 1.28 \\
Marine transportation & $\mathrm{t} \cdot \mathrm{km}$ & $6993-14,297$ & $\mathrm{Zn}$ & $\mathrm{g}$ & 0.64 \\
Road transport & $\mathrm{t} \cdot \mathrm{km}$ & 144 & $\mathrm{Mg}$ & $\mathrm{kg}$ & 6.6 \\
Water emissions & & & $\mathrm{Ca}$ & $\mathrm{kg}$ & 422.2 \\
$\mathrm{Mg}^{+2}$ & $\mathrm{~kg}$ & 6.6 & $\mathrm{~K}$ & $\mathrm{~kg}$ & 10.8 \\
$\mathrm{Ca}^{+2}$ & $\mathrm{~kg}$ & 422 & $\mathrm{Na}$ & $\mathrm{kg}$ & 44.2 \\
$\mathrm{~K}^{+}$ & $\mathrm{kg}$ & 10.8 & $\mathrm{Cl}$ & $\mathrm{kg}$ & 839.8 \\
$\mathrm{Na}^{+}$ & $\mathrm{kg}$ & 44.2 & & & \\
$\mathrm{Cl}^{-}$ & $\mathrm{kg}$ & 840 & & & \\
$\mathrm{~B}^{+3}$ & $\mathrm{~g}$ & 50 & & & \\
$\mathrm{Cr}$ & $\mathrm{g}$ & 1.28 & & & \\
$\mathrm{Zn}$ & $\mathrm{g}$ & 0.64 & & & \\
& & & & & \\
\hline
\end{tabular}


Most refractory grade sintered spinels are made from a combination of high purity synthetic aluminum oxide $\left(\mathrm{Al}_{2} \mathrm{O}_{3}\right)$ and chemical-grade $\mathrm{MgO}$. In this production, $\mathrm{MgCO}_{3}$ is the starting material for $\mathrm{MgO}$. Its solid state synthesis from magnesia and alumina occurs by interdiffusion $\left(3 \mathrm{Mg}^{2+} \leftrightarrow 2 \mathrm{Al}^{3+}\right)$ of cations through the product layer between the oxide particles, necessitating the use of high processing temperatures $\left(>1400-1500{ }^{\circ} \mathrm{C}\right)$. Synthesis takes place either in a shaft kiln for sintered spinel. The advantage of sintered spinel is that this is a continuous ceramic process, with controlled feed-rate and uniform temperature distribution in the kiln, leading to a homogeneous product that contributes to the excellent high-temperature properties. Life cycle inventory data of sintered spinel production are given in Table 3.

Table 3. Life cycle inventory data of one ton of sintered spinel.

\begin{tabular}{ccc}
\hline Natural Resources & Unit & Amount \\
\hline $\mathrm{MgCO}_{3}$ & $\mathrm{~kg}$ & 688 \\
\hline Materials and energy & & \\
\hline Heavy fuel oil & $\mathrm{GJ}$ & 3.52 \\
$\mathrm{Al}_{2} \mathrm{O}_{3}$ & $\mathrm{~kg}$ & 653 \\
Electricity & $\mathrm{kWh}$ & 72.22 \\
Marine transportation & $\mathrm{t} \cdot \mathrm{km}$ & 17,946 \\
Land transport & $\mathrm{t} \cdot \mathrm{km}$ & 141.552 \\
\hline \multicolumn{1}{c}{ Emissions } & & \\
\hline $\mathrm{SO}_{2}$ & $\mathrm{~g}$ & 165.4 \\
$\mathrm{CO}$ & $\mathrm{g}$ & 232.3 \\
$\mathrm{NO}_{\mathrm{x}}$ & $\mathrm{kg}$ & 1.81 \\
$\mathrm{CO}_{2}$ & $\mathrm{~kg}$ & 619 \\
$\mathrm{PM}<10$ & $\mathrm{~g}$ & 70.4 \\
$\mathrm{PM}<2.5$ & $\mathrm{~g}$ & 70.4 \\
\hline Non methanogenic volatile organic matter (NMVOC) & $\mathrm{g}$ & 88 \\
\hline
\end{tabular}

\section{Experimental}

Raw materials were taken into silos in various fractions after the crushing/milling and sieving processes. Material and energy inventories of refractory brick production process can be seen in Table 4 according to the functional unit. Measurement of the gas emissions during firing was carried out by an accredited laboratory during the magnesia spinel refractory brick production process.

Table 4. Material and energy inventories of the production of one ton of refractory brick.

\begin{tabular}{ccc}
\hline Materials and Energy & Unit & Amount \\
\hline SWSM-1 & $\mathrm{kg}$ & 425 \\
SWSM-2 & $\mathrm{kg}$ & 425 \\
Sintered spinel & $\mathrm{kg}$ & 150 \\
Water & $\mathrm{m}^{3}$ & 25 \\
Electricity & & \\
Crushing/milling and sieving & $\mathrm{kWh}$ & 100 \\
Weighing/batch preparation & $\mathrm{kWh}$ & 40 \\
Dry pressing & $\mathrm{kWh}$ & 100 \\
Natural gas & $\mathrm{kcal}$ & 782,025 \\
Packaging (carton, plastic) & $\mathrm{kg}$ & 3.5 \\
\hline
\end{tabular}

$\mathrm{CO}$ and $\mathrm{CO}_{2}, \mathrm{NO}_{\mathrm{x}}$ and $\mathrm{SO}_{2}$ were determined by electrochemical cell method according to TS ISO 12039, EPA CTM-022 and ISO 7935, respectively. Particulate matter was withdrawn isokinetically from the source and collected on a glass fiber filter and was determined gravimetrically after the removal of uncombined water (TS ISO 9096, TS EN 13284-1). Hydrogen fluoride and 
hydrogen chloride concentrations were determined with alkaline absorbing solutions in samples that are withdrawn isokinetically (EPA Method $26 \mathrm{~A}$ ). Concentrations of volatile organic compounds (VOC) were obtained by activated carbon and solvent desorption method (TS EN 13649). For heavy metal analyses, a stack sample was withdrawn isokinetically from the source, particulate emissions were collected with a probe on a heated filter, and gaseous emissions were then collected in an aqueous acidic solution. Then, the recovered samples were digested and analyzed with ICP-OES (EPA Method 29). Formaldehyde concentration was determined according to acetyl acetone colorimetric method (EPA Method 323). The results are given for one ton of brick production in Table 5. The solid waste below $2.5 \mathrm{wt} \%$ was neglected.

Table 5. Gas emissions during production of one ton of refractory brick.

\begin{tabular}{cccc}
\hline Emission & Amount (g) & Emission & Amount (g) \\
\hline $\mathrm{CO}$ & 3237 & O-xylene & 0.954 \\
$\mathrm{CO}_{2}$ & 425.785 & Isopropyl benzene & 0.083 \\
$\mathrm{SO}_{2}$ & 2465 & n-propyl benzene & 0.215 \\
$\mathrm{NO}_{\mathbf{x}}$ & 183 & Trimethyl benzene & 0.895 \\
Particulate matter & 30.2 & Butylbenzenes & 0.936 \\
Hydrogen fluoride & 38.25 & 4-Isopropyltoluen & 0.264 \\
Hydrogen chloride & 23.44 & Naphthalene & 0.123 \\
4-chlorotoluene & 0.921 & Formaldehyde & 1.99 \\
2-chlorotoluene & 0.914 & Arsenic & 0.0729 \\
1,1,2,2-tetrachloroethane & 20.370 & Chromium & 0.1102 \\
Benzene & 5.149 & Cadmium & 0.0044 \\
Toluene & 7.916 & Copper & 0.1248 \\
p+m xylene & 1.504 & Manganese & 0.0189 \\
Ethylbenzene & 1.496 & Nickel & 0.0038 \\
Styrene & 0.698 & Lead & 0.0970 \\
& & Titanium & 0.2011 \\
\hline
\end{tabular}

\subsubsection{Life Cycle Impact Assessment}

Eight impact categories included by the CML-IA baseline (v.3) method were investigated: abiotic depletion (elements and fossil fuel) ( $\mathrm{kg} \mathrm{Sb}$ eq. and $\mathrm{MJ}$ ), acidification ( $\mathrm{kg} \mathrm{SO}_{2}$ eq.), photochemical oxidation ( $\mathrm{kg} \mathrm{C}_{2} \mathrm{H}_{4}$ eq.), global warming potential ( $\mathrm{kg} \mathrm{CO}_{2}$ eq.), ozone layer depletion (kg CFC-11 eq.), eutrophication ( $\mathrm{kg} \mathrm{PO}_{4}{ }^{3-}$ eq.), human toxicity ( $\mathrm{kg} 1,4-\mathrm{DB}$ eq.), and ecotoxicity (fresh water, marine aquatic, and terrestrial) (kg 1,4-DB eq.). All the impact calculations were performed with the licensed LCA software SimaPro 8.0.1.

\subsection{Life Cycle Cost (LCC) Analysis}

In this part of the study, LCC analysis of the refractory bricks production process was carried out in five steps (Figure 2). The functional unit was selected as "one ton of magnesia spinel refractory brick" and the system boundaries were taken as LCA studies.

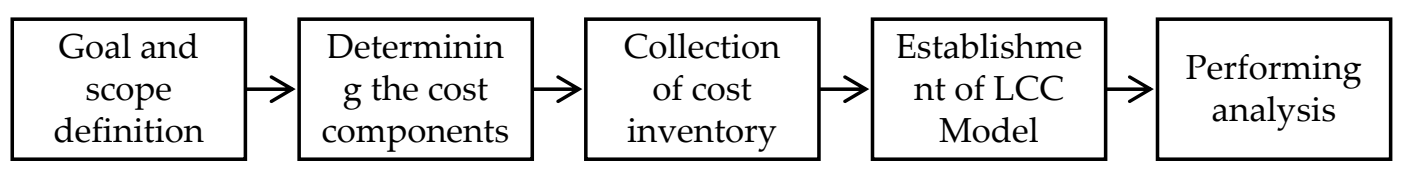

Figure 2. LCC methodology.

Cost components of the production of one ton of magnesia spinel refractory brick were examined in two parts: internal and external (Table 6). 
Table 6. Classification of life cycle cost components.

\begin{tabular}{ccc}
\hline LCC Cost & LCC Component & LCC Subcomponent \\
\hline \multirow{3}{*}{ Internal } & Raw materials & Raw materials and transportation cost \\
& Production & Energy cost \\
& & Labor cost \\
& & Maintenance cost \\
& Packaging cost \\
\hline \multirow{2}{*}{ External } & Pollutant costs & Eutrophication \\
& & Acidification \\
& & Photochemical oxidation \\
& & Ozone layer depletion \\
& & Global warming \\
& & Toxicity (Human toxicity, ecotoxicity) \\
\hline
\end{tabular}

Internal cost data regarding the refractory brick production were obtained from the plant and the relevant literature [30]. The results of the LCA study were used for environmental costs. Internal and external costs are given in Tables 7 and 8. Unit costs for external costs were obtained from Banar and Özdemir (2015) [30].

Table 7. Internal cost inventory for one ton of magnesia spinel refractory brick.

\begin{tabular}{cccccc}
\hline Cost Items & Unit & Amount & Unit Cost & Cost (\$) & Source \\
\hline Natural gas & $\mathrm{m}^{3}$ & 75 & $0.32 \$ / \mathrm{m}^{3}$ & 24 & {$[40]$} \\
Crushing-Milling-Sieving & $\mathrm{kWh}$ & 100 & $0.095 \$ / \mathrm{kWh}$ & 9.50 & {$[41]$} \\
Forming & $\mathrm{kWh}$ & 100 & $0.095 \$ / \mathrm{kWh}$ & 9.50 & {$[41]$} \\
Weighing-Batch Preparation & $\mathrm{kWh}$ & 40 & $0.095 \$ / \mathrm{kWh}$ & 3.80 & {$[41]$} \\
Labor & $\$$ & 62.74 & $1 \$ / \$$ & 62.74 & The plant \\
Maintenance & $\mathrm{kg}$ & 1000 & $0.03 \$ / \mathrm{kg}$ & 30 & The plant \\
Packaging & $\mathrm{kg}$ & 11.3 & $3.2 \$ / \mathrm{kg}$ & 36.16 & The plant \\
\hline
\end{tabular}

Table 8. External costs.

\begin{tabular}{cccc}
\hline Environmental Indicators & Amount & Unit Cost (\$/kg) & Cost (\$) \\
\hline Acidification (kg SO ${ }_{2}$ eq.) & 38.62 & 9.2 & 355.304 \\
Photochemical oxidation (kg C $\mathrm{H}_{4}$ eq.) & 2.81 & 2.4 & 6.744 \\
Ozone layer depletion (kg CFC-11 eq.) & 1.2 & 371.3 & 445.56 \\
Global warming (kg CO eq. $^{2}$ & 386.72 & 0.137 & 52.98 \\
Eutrophication (kg PO ${ }_{4}^{3-}$ eq.) & 0.676 & 4.37 & 2.95 \\
\hline \multicolumn{5}{c}{ Toxicity (kg 1,4 DB eq.) } \\
Benzene & 0.07 & 0.08436 & $5.91 \times 10^{-3}$ \\
Formaldehyde & $1.90 \times 10^{-9}$ & 0.2442 & $4.64 \times 10^{-10}$ \\
Arsenic & $7.57 \times 10^{-5}$ & 387.4 & $1.85 \times 10^{-5}$ \\
Cadmium & $1.24 \times 10^{-4}$ & 31.9 & $3.96 \times 10^{-3}$ \\
Lead & $3.20 \times 10^{-4}$ & 1061.50 & 0.3397 \\
Mercury & 0.053 & 1001 & 53.053 \\
Nickel & $2.2 \times 10^{-3}$ & 4.18 & $9.196 \times 10^{-3}$ \\
\hline
\end{tabular}

The structure of the method consists of four components: general properties, characterization, damage assessment, and weighting. These general properties were the first component in the creation of a new economic method in the software. As a next step, characterization, the required cost types together with their unit cost $(\$ / \mathrm{kg})$ were added under "impact category". Damage assessment was the second component, which was defined in the top level cost category as "damage category". In the easiest case, everything is in one currency and at one time; the factor will then be 1 . Weighting was the 
final component on the method. A weighting factor has been entered as " 1 " for simple addition of all cost categories, which is often a useful approach. Normalization has not been taken into account since it is commonly not applied in LCC.

\section{Results}

\subsection{LCA Results}

According to the CML-IA method, total life cycle assessment results of one ton of magnesia spinel refractory brick are summarized in Table 9 and total characterization and normalization results are given in Supplementary Materials (Tables S1 and S2). According to the tables, marine aquatic ecotoxicity, acidification, and global warming potential are the main effects. The distributions of indicators based on the processes are given in the Supplementary Materials (Figure S1).

Table 9. Total LCA characterization results.

\begin{tabular}{ccc}
\hline Impact Category & Unit & Total \\
\hline Abiotic depletion (element) & kg Sb eq. & $1.42 \times 10^{-5}$ \\
Abiotic dep. (fossil fuels) & $\mathrm{MJ}$ & $2.42 \times 10^{4}$ \\
Global warming (GWP100a) & $\mathrm{kg} \mathrm{CO}$ eq. & $8.35 \times 10^{3}$ \\
Ozone layer depletion (ODP) & $\mathrm{kg} \mathrm{CFC-11} \mathrm{eq.}$ & $1.88 \times 10^{-4}$ \\
Human toxicity & $\mathrm{kg} \mathrm{1,4-DB} \mathrm{eq.}$ & $1.68 \times 10^{3}$ \\
Fresh water aquatic ecotoxicity & $\mathrm{kg} \mathrm{1,4-DB} \mathrm{eq.}$ & $2.11 \times 10^{2}$ \\
Marine aquatic ecotoxicity & $\mathrm{kg} \mathrm{1,4-DB} \mathrm{eq.}$ & $2.03 \times 10^{7}$ \\
Terrestrial ecotoxicity & $\mathrm{kg} \mathrm{1,4-DB} \mathrm{eq.}$ & $1.87 \times 10^{0}$ \\
Photochem. oxidation form & $\mathrm{kg} \mathrm{C}_{2} \mathrm{H}_{4}$ eq. & $3.25 \times 10^{0}$ \\
Acidification & $\mathrm{kg} \mathrm{SO}_{2}$ eq. & $4.70 \times 10^{1}$ \\
Eutrophication & $\mathrm{kg} \mathrm{PO}_{4}{ }^{3-}$ eq. & $1.61 \times 10^{0}$ \\
\hline
\end{tabular}

Element basis Abiotic Depletion Potential (ADPe) is related with consumption of elements and minerals. The effect of two different sea water magnesia to ADPe were almost the same (37\%) and higher than the others. The effect of these stages are followed by crushing $/ \mathrm{milling} / \mathrm{sieving}(7.51 \%)$, forming $(7.51 \%)$, and sintered spinel process (5.54\%). Chromium (45.1\%), uranium (39.9\%), and nickel $(10.3 \%)$ cause this effect because of raw material extraction.

Fossil fuels basis ADP (ADPff) impacts of SWSM- 1 and SWSM-2 are 35\% and 33\%, respectively. Natural gas consumption is the dominant effect $(61 \%)$ in the ADPff. It is followed by coal $(21 \%)$ and crude oil consumption (18\%).

Acidification potential (AP) mainly resulted from drying and firing process emissions with $84.1 \%$. Impact percentages of SWSM-1, SWSM-2 and sintered spinel are low compared to the drying/firing process. On a pollutant parameter basis, it was determined that the $\mathrm{SO}_{2}$ and $\mathrm{NO}_{\mathrm{x}}$ contents of stack gas have the greatest effect on the acidification potential at $92.5 \%$ and $7.4 \%$, respectively.

Eutrophication Potential (EP) mainly results due to emission of nitrogenous and phosphorous compounds. The SWSM-1 and SWSM-2 production are influenced by $32.5 \%$ and $32 \%$, respectively. These productions are followed by the firing process of the refractory brick $(20.5 \%)$, sintered spinel production, and other subprocesses in refractory brick production.

Global Warming Potential (GWP) is affected mainly by the firing process in the refractory brick production $(68.6 \%)$. The effects of two different sea water magnesia on global warming potential are $13.5 \%$ and $13.2 \%$ for SWSM- 1 and SWSM-2, respectively. It is determined that $\mathrm{CO}_{2}$ emissions released into the atmosphere during the calcination process in sintered magnesia production cause this impact.

Ozone Depletion Potential (ODP) is affected by seawater magnesia production by about $70 \%$. Other subcategories that affect the ozone layer depletion are drying/firing process and sintered spinel production. Halogenated gases resulting from the drying and firing processes in refractory brick production and sintered magnesia production are the dominant causes this impact. 
Photochemical Oxidation Potential (POP) is primarily influenced by the drying/firing processes during refractory brick production, by $87 \%$, due to the emissions in the stack. It is followed by raw materials (SWSM-1, SWSM-2, and sintered spinel) production.

Human Toxicity Potential (HTP) is affected by the drying and firing processes in refractory brick production (93\%) because of hydrogen fluoride and benzene emissions. Emissions into water have a significant effect on human toxicity, with prominent elements including selenium, vanadium, nickel, and barium.

Marine Aquatic Ecotoxicity Potential (MAETP) is affected by refractory brick production ( $98.8 \%$ ) due to the effect of fluorinated gases. Emissions into water have a significant effect on MAETP, with prominent elements including vanadium, beryllium, nickel, cobalt, and selenium.

Fresh Water Aquatic Ecotoxicity Potential (FAETP) is caused by seawater magnesia production $(97 \%)$. It is determined that fluorinated gas emissions cause FAETP; and prominent elements in water emissions are nickel, copper, beryllium, and arsenic.

Terrestrial Ecotoxicity Potential (TEP) is contributed by SWSM-1 (40.4\%) and SWSM-2 (38.8\%) production. This occurs during extraction of raw materials for magnesite production. In addition, chromium (VI), zinc, nickel, beryllium, and formaldehyde, released during electricity generation for forming and crushing/milling processes, etc., have a significant effect on terrestrial ecotoxicity.

\subsection{LCC Results}

The LCC results of one ton of magnesia spinel refractory brick and distribution of cost components are given in Table 10. According to the results, total cost is mainly shared by external and internal costs with percentages of $60 \%$ and $33 \%$, respectively. When considering environmental costs, $83.9 \%$ represents refractory production, the most affected subcategory. This is followed by seawater magnesia production. In addition to this observation from Table 10, although SWSM-1 and SWSM-2 are supplied from two different plants from abroad, these plants have almost the same environmental costs (\$492 and $\$ 483$, respectively).

Table 10. LCC results of one ton of magnesite-spinel refractory brick.

\begin{tabular}{|c|c|c|c|c|c|c|}
\hline \multicolumn{2}{|c|}{ Cost Categories } & \multicolumn{3}{|c|}{ Raw Material Production } & \multirow{2}{*}{$\begin{array}{l}\text { Refractory Brick } \\
\text { Production }\end{array}$} & \multirow{2}{*}{ Total Costs } \\
\hline & & SWSM-1 & SWSM-2 & Sinter Spinel & & \\
\hline \multirow{5}{*}{$\begin{array}{l}\text { Internal } \\
\text { costs }(\$)\end{array}$} & $\begin{array}{l}\text { Raw material and } \\
\text { transportation }\end{array}$ & $298(60.6 \%)$ & $298(61.7 \%)$ & $155(74.9 \%)$ & - & $751(33.0 \%)$ \\
\hline & Energy & - & - & - & $47(4.3 \%)$ & $47(2.1 \%)$ \\
\hline & Labor & - & - & - & $63(5.8 \%)$ & $63(2.8 \%)$ \\
\hline & Packaging & - & - & - & $36(3.3 \%)$ & $36(1.6 \%)$ \\
\hline & Maintenance & - & - & - & $30(2.7 \%)$ & $30(1.3 \%)$ \\
\hline $\begin{array}{l}\text { External } \\
\text { costs }(\$)\end{array}$ & $\begin{array}{l}\text { Environmental } \\
\text { costs }\end{array}$ & $194(39.4 \%)$ & $185(38.3 \%)$ & $52(25.1 \%)$ & $917(83.9 \%)$ & $1348(59.3 \%)$ \\
\hline \multicolumn{2}{|c|}{ Total Cost (\$) } & $492(100 \%)$ & $\begin{array}{c}483(100 \%) \\
52 \%\end{array}$ & $207(100 \%)$ & $\begin{array}{c}1093(100 \%) \\
48 \%\end{array}$ & $2275(100 \%)$ \\
\hline
\end{tabular}

Considering the environmental costs of the production of one ton of magnesite spinel refractory brick based on impact categories, it is observed that the maximum cost among the categories is attributed to ozone layer depletion.

\subsection{Sensitivity Analysis}

Environmental performance of refractory brick production can be improved with the best available techniques. According to EIPPCB (European Integration Pollution Prevention Control Bureau) documents, the energy requirements for the drying/firing process of magnesite-containing refractories are given in Table 11. 
Table 11. Energy consumption for the manufacture of magnesia refractory bricks [1].

\begin{tabular}{cc}
\hline Process & Energy Requirement $(\mathbf{M J} / \mathbf{k g})$ \\
\hline Crushing/Milling/Sieving & $0.35-0.50$ \\
Weighing/Batch Preparation & $0.045-0.070$ \\
Forming & $0.13-0.20$ \\
Drying, Firing & $3.0-6.3$ \\
Packaging & 0.08 \\
\hline
\end{tabular}

According to Best Available Technologies Reference (BREF) documents, the energy requirement for the drying / firing process of magnesite = containing refractories is about $3-6.3 \mathrm{MJ} / \mathrm{kg}$. When the energy consumption is reduced from the current system to $3 \mathrm{MJ} / \mathrm{kg}$ (decreased by $8.4 \%$ ) in the firing process of refractory production, a refractory plant can reach the minimum energy value given in the EIPPCB document. Table 12 shows the minimum and maximum emission values of magnesite containing refractories in BREF documents.

Table 12. Raw gas values of different refractory products (EIPPCB, 2007a).

\begin{tabular}{cccc}
\hline Emission & \multicolumn{3}{c}{ Concentration $\left(\mathbf{m g} / \mathbf{m}^{3}\right)$} \\
\hline Product & Magnesite & High Alumina & Silica \\
\hline Dust & $8-35$ & $5-80$ & $10-25$ \\
$\mathrm{NO}_{2}$ & $110-470$ & $30-250$ & $5-100$ \\
$\mathrm{SO}_{2}$ & $90-580$ & $10-430$ & $20-150$ \\
$\mathrm{CO}$ & $12-180$ & $30-150$ & $10-50$ \\
$\mathrm{HF}$ & $0.5-1.5$ & $5-50$ & $1-3$ \\
\hline
\end{tabular}

For sensitivity analysis, energy consumption is reduced by $8.4 \%$ and emission values are decreased according to the BREF document. Sensitivity analyses were performed in two what-if scenarios: (i) energy reduction only; (ii) energy reduction and emissions decreasing. A graph is given in Figure 3. It shows that an $8.4 \%$ energy decrease s slightly lowers some environmental impact values. It is seen that human toxicity, marine aquatic ecotoxicity, photochemical oxidation formation, and acidification effects are decreased by a reduction in energy and emissions. As human toxicity is related to the HF component, reduction of this emission value decreases this impact category by $51 \%$. Reduction of fluoride gas emissions decreases the marine aquatic ecotoxicity impact category by $60 \%$. Change in the amount of $\mathrm{SO}_{2}$ affects some impact categories, especially acidification, and leads to a decrease in these impact categories by $5.4 \%$. $\mathrm{SO}_{2}$ emissions from firing process of refractory brick production causes photochemical oxidation and reduction of this emission component provides an improvement of this impact category by $35 \%$.

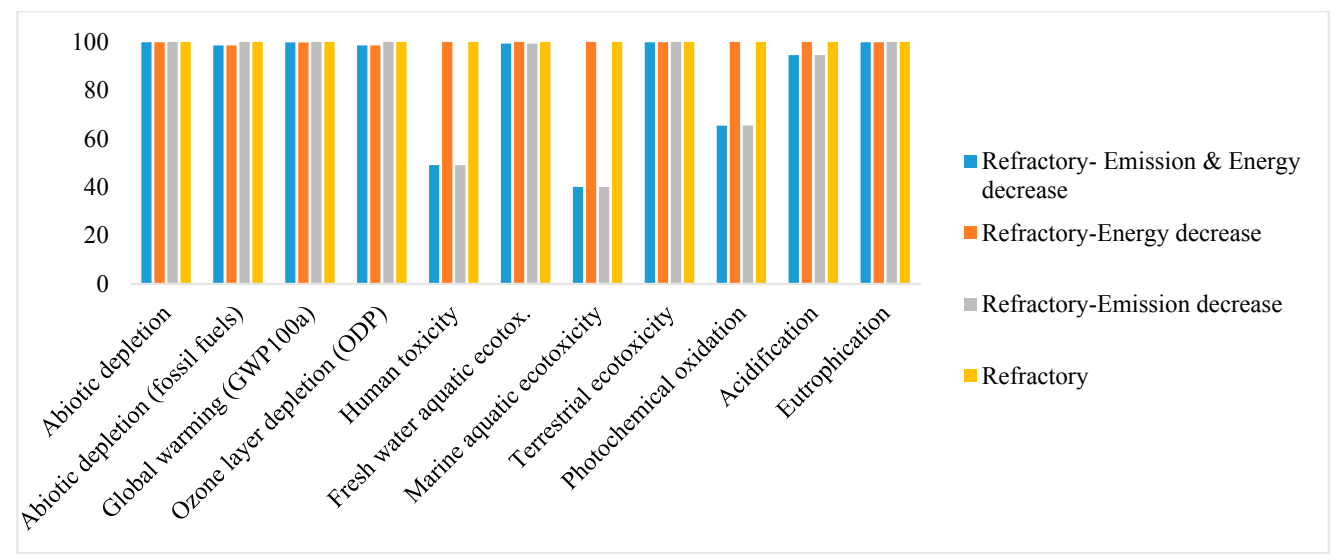

Figure 3. Sensitivity analysis results. 


\section{Discussion}

The environmental impacts of the magnesia spinel refractory brick production process mainly resulted from the drying/firing process. The emissions of fluorinated gases $\mathrm{SO}_{2}, \mathrm{NO}_{\mathrm{x}}$, and $\mathrm{CO}_{2}$ during the production process contributed to marine aquatic ecotoxicity, acidification, and potential global warming. The seawater-sintered magnesite production process is another important process due to raw material consumption, halogenated, phosphorus, and heavy metal emissions. Raw material consumption caused abiotic depletion while emissions are responsible for eutrophication, ozone layer depletion, and freshwater aquatic and terrestrial ecotoxicity. Stack gas released during the sintering process also has a negative effect on the environment due to its VOC and CO content. Taking these results into consideration, it can be suggested that air pollution control equipment should be improved in order to decrease the environmental impacts. An activated carbon unit will be able to remove the VOC constituent. The presence of $\mathrm{CO}$ indicates that the combustion process has an inappropriate air/fuel (A/F) ratio. Thus, further improvement is also required in A/F for CO and VOC removal.

LCA and LCC, when carried out in an integrated manner and from a systems perspective, have a high potential for moving industrial practice towards sustainable development. Furthermore, an LCC analysis integrated with LCA may contribute to more sustainable decision-making in refractory industries, taking into account long-term costs and environmental consequences. Environmental costs account for approximately $60 \%$ of the total cost of this process due to emissions.

\section{Conclusions}

This study shows that LCA and LCC are useful tools to determine the environmental and economic performance of refractory materials. In addition to this, the results can be used to prepare a Product Category Rule (PCR) since there is no certain PCR on magnesia spinel refractory brick production. A prepared PCR would increase the refractory products with EPD certificate on the construction area.

Finally, a comparable environmental database would be obtained to select the product with the highest environmental performance.

Supplementary Materials: The following are available online at www.mdpi.com/2071-1050/8/7/662/s1. Figure S1: Distribution of indicators based on processes, Table S1: LCA characterization results, Table S2: LCA normalization results.

Acknowledgments: This study was supported by TUBITAK (The Scientific and Technological Research Council of Turkey) under Grant No. 114Y525.

Author Contributions: Melike Metesoy observed the data, Levent Karacasulu and Gülden Tok analyzed the data with LCA and LCC, Alpagut Kara supervised refractory production process, and Zerrin Günkaya, Aysun Özkan, and Müfide Banar interpreted the LCA and LCC results. All authors have read and approved the final manuscript.

Conflicts of Interest: The authors declare no conflict of interest.

\section{References}

1. EIPPCB (European Integration Pollution Prevention Control Bureau). Reference Document on Best Available Techniques in the Ceramic Manufacturing Industry; European Commission: Brussels, Belgium, 2007.

2. Lule-Gonzalez, R.G.; Lopez-Acosta, F.; Rodriguez, R. Recycling MgO-C Refractory in the EAF of Mittal Steel Lazaro Cardenas. AIST Iron Steel Technol. 2006, 1, 76-84.

3. Nakamura, Y.; Hirai, N.; Tsutsui, Y.; Uchinokura, K.; Tamura, S.I. Recycling of refractories in the steel industry. Indian Ceram. 1999, 19, 111-114.

4. Valoref, A.O. Recovery and recycling of scrap refractories. World Ceram. Refract. 1998, 9, $13-16$.

5. Republic of Turkey Ministry of Environment and Urbanization. Turkish Regulation on Monitoring of Greenhouse Gas (GHG), No. 29003, 17 May 2014. Available online: http:/ /www.mevzuat.gov.tr (accessed on 11 July 2016). (In Turkish)

6. The Construction Products Directive (89/106/EEC). 1989. Available online: http:/ /eurocodes.jrc.ec.europa. eu/doc/construction_products_directive.pdf (accessed on 11 July 2016). 
7. Khasreen, M.M.; Banfill, P.; Menzies, G.F. Life-Cycle Assessment and the Environmental Impact of Buildings: A Review. Sustainability 2009, 1, 674-701. [CrossRef]

8. Almeida, M.I.; Dias, A.C.; Demertzi, M.; Arroja, L. Contribution to the development of product category rules for ceramic bricks. J. Clean. Prod. 2015, 92, 206-215. [CrossRef]

9. Han, B.; Wang, R.; Yao, L.; Liu, H.; Wang, Z. Life cycle assessment of ceramic façade material and its comparative analysis with three other common façade materials. J. Clean. Prod. 2015, 99, 86-93. [CrossRef]

10. Kim, K.H. A comparative life cycle assessment of a transparent composite façade system and a glass curtain wall system. Energy Build. 2011, 43, 3436-3445. [CrossRef]

11. Souza, D.M.; Lafontaine, M.; Charron-Doucet, F.; Bengoa, X.; Chappert, B.; Duarte, F.; Lima, L. Comparative Life Cycle Assessment of ceramic versus concrete roof tiles in the Brazilian context. J. Clean. Prod. 2015, 89, 165-173. [CrossRef]

12. Cabeza, L.F.; Rincon, L.; Vilarino, V.; Perez, G.; Castell, A. Life cycle assessment (LCA) and life cycle energy analysis (LCEA) of buildings and the building sector: A review. Renew. Sust. Energy Rev. 2014, 29, 394-416. [CrossRef]

13. Almeida, M.; Dias, A.C.; Arroja, L. Environmental product declaration in Portuguese ceramic tile. In Proceedings of the SIM 2011 International Conference on Sustainable Intelligent Manufacturing, Leiria, Portugal, 29 June-1 July 2011.

14. Bribian, I.Z.; Capilla, A.V.; Uson, A.A. Life cycle assessment of building materials: comparative analysis of energy and environmental impacts and evaluation of the eco-efficiency improvement potential. Build. Environ. 2011, 46, 1133-1140. [CrossRef]

15. Banar, M.; Çokaygil, Z. Environmental Evaluation of Ceramic Floor Tiles through Life Cycle Analysis Method. In Proceedings of the Solid Waste Management Symposium in Turkey (TÜRKAY 2009), Istanbul, Turkey, 15-17 June 2009.

16. Bovea, M.D.; Saura, U.; Ferrero, J.L.; Giner, J. Cradle to gate study of red clay for use in the ceramic industry. Intl. J. Life Cycle Assess. 2007, 12, 439-447. [CrossRef]

17. Koroneos, C.; Dompros, A. Environmental assessment of brick production in Greece. Build. Environ. 2007, 42, 2114-2123. [CrossRef]

18. Nicoletti, G.M.; Notarnicola, B.; Tassielli, G. Comparative Life Cycle Assessment of flooring materials: Ceramic versus marble tiles. J. Clean. Prod. 2002, 10, 283-296. [CrossRef]

19. Rouwette, R. LCA of Brick Products: Life Cycle Assessment Report E Final Report after Critical Review; Think Brick Australia J/N 107884; Energetics: Melbourne, Australia, 2010.

20. Boesch, M.E.; Hellweg, S. Identifying improvement potentials in cement production with life cycle assessment. Environ. Sci. Technol. 2010, 44, 9143-9149. [CrossRef] [PubMed]

21. Chen, C.; Habert, G.; Bouzidi, Y.; Jullien, A. Environmental impact of cement production: Detail of the different processes and cement plant variability evaluation. J. Clean. Prod. 2010, 18, 478-485. [CrossRef]

22. Feiz, R.; Ammenberg, J.; Baas, L.; Eklund, M.; Helgstrand, A.; Marshall, R. Improving the $\mathrm{CO}_{2}$ performance of cement, part II: Framework for assessing $\mathrm{CO}_{2}$ improvement measures in cement industry. J. Clean. Prod. 2015, 98, 282-291. [CrossRef]

23. Güeraca, L.P.; Torres, N.; Juarez-Lopez, C.R. The co-processing of municipal waste in a cement kiln in Mexico. A life-cycle assessment approach. J. Clean. Prod. 2015, 107, 741-748. [CrossRef]

24. Valderrama, C.; Granados, R.; Cortina, J.L.; Gasol, C.M.; Guillem, M.; Josa, A. Implementation of best available techniques in cement manufacturing: A lifecycle assessment study. J. Clean. Prod. 2012, 25, 60-67. [CrossRef]

25. Huntzinger, D.N.; Eatmon, T.D. A life-cycle assessment of Portland cement manufacturing: Comparing the traditional process with alternative technologies. J. Clean. Prod. 2009, 17, 668-675. [CrossRef]

26. Vares, S.; Hakkinen, T. LCA Tool for Cement Manufacturers for System Optimization and for Environmental Reporting; Koukkari, H., Nors, M., Eds.; Life Cycle Assessment of Products and Technologies: Espoo, Finland, 2009; pp. 122-133.

27. Simoes, C.L.; Costa Pinto, L.M.; Bernardo, C.A. Environmental and economic assessment of a road safety product made with virgin and recycled HDPE: A comparative study. J. Environ. Manag. 2013, 114, $209-215$. [CrossRef] [PubMed]

28. Asiedu, Y.; Gu, P. Product life cycle cost analysis: State of the art review. Intl. J. Prod. Res. 1998, 36, 883-908. [CrossRef] 
29. Norris, G.A. Integrating Life Cycle Cost Analysis and LCA. Intl. J. LCA 2001, 6, 118-120.

30. Banar, M.; Özdemir, A. An evaluation of railway passenger transport in Turkey using life cycle assessment and life cycle cost methods. Transp. Res. D 2015, 41, 88-105. [CrossRef]

31. Chou, J.S.; Yeh, K.C. Life cycle carbon dioxide emissions simulation and environmental cost analysis for building construction. J. Clean. Prod. 2015, 101, 137-147. [CrossRef]

32. Abdul-Wahab, S.A.; Al-Rawas, G.A.; Ali, S.; Al-Dhamri, H. Impact of the addition of oil-based mud on carbon dioxide emissions in a cement plant. J. Clean. Prod. 2015, 112, 4214-4225. [CrossRef]

33. Curran, M.A. Life Cycle Assessment Handbook: A Guide for Environmentally Sustainable Products; Wiley: Hoboken, NJ, USA, 2012.

34. Baumann, H.; Tillman, A. The Hitch Hiker's Guide to LCA: An Orientation in Life Cycle Assessment Methodology and Applications; Studentlitteratur AB: Lund, Sweden, 2004.

35. International Organization for Standardization. Environmental Management_Life Cycle Assessment_Principles and Framework; International Standard ISO 14040:2006; International Organization for Standardization: Geneva, Switzerland, 2006.

36. International Organization for Standardization. Environmental Management_Life Cycle Assessment_Requirements and Guidelines; International Standard ISO 14044:2006; International Organization for Standardization: Geneva, Switzerland, 2006.

37. EIPPCB. Reference Document on Best Available Techniques in Large Volume Inorganic Chemicals—Solids and the Others Industry; European Commission: Brussels, Belgium, 2007.

38. Guinée, J.B.; Gorrée, M.; Heijungs, R.; Huppes, G.; Kleijn, R.; de Koning, A.; van Oers, L.; Wegener Sleeswijk, A.; Suh, S.; Udo de Haes, H.A.; et al. Handbook on Life cycle Assessment. Operational Guide to the ISO Standards. Part III: Scientific Background; Kluwer Academic Publishers: Dordrecht, The Netherlands, 2002; p. 692.

39. Tok, G. Evaluation of Refractory Brick Production through Life Cycle Assessment and Life Cycle Cost Methods. Master's Thesis, Anadolu University, Eskisehir, Turkey, 2015.

40. BOTAS. Available online: http:/ / www.botas.gov.tr (accessed on 1 June 2015). (In Turkish)

41. TEDAS. Available online: http:/ / www.tedas.gov.tr (accessed on 1 June 2015). (In Turkish)

(C) 2016 by the authors; licensee MDPI, Basel, Switzerland. This article is an open access article distributed under the terms and conditions of the Creative Commons Attribution (CC-BY) license (http://creativecommons.org/licenses/by/4.0/). 